\title{
Is phosphodiesterase type 5 inhibitor use associated with condom breakage?
}

\author{
R Crosby, ${ }^{1,2,3}$ W L Yarber, ${ }^{2,3,4}$ S A Sanders, ${ }^{2,3,4}$ C A Graham ${ }^{2,3,4,5,6}$
}

${ }^{1}$ College of Public Health at the University of Kentucky, Kentucky, USA; ${ }^{2}$ The Kinsey Institute for Research in Sex Gender, and Reproduction, Indiana, USA; ${ }^{3}$ Rural Center for AIDS/STD Prevention at Indiana University, Indiana, USA;

${ }^{4}$ Department of Applied Health Science, Indiana University, Indiana, USA; ${ }^{5}$ Department of Gender Studies, Indiana University, Indiana, USA

${ }^{6}$ Oxford Doctoral Course in Clinical Psychology, Oxford, UK

Correspondence to:

Richard Crosby, College of Public Health, 121 Washington Ave. Lexington, Kentucky 405060003, USA; crosby@uky.edu

Accepted 13 March 2009

\section{ABSTRACT}

We tested the hypothesis that phosphodiesterase type 5 inhibitor (PDE5i) use would be associated with increased likelihood of condom breakage using an event-specific analysis.

A convenience sample of 440 men completed an internetbased questionnaire that assessed variables pertaining to the last time they used condoms for penile-vaginal intercourse (PVI). A bivariate (screening) analysis was performed to identify covariates for a multivariate analysis using logistic regression.

Altogether, $5.9 \%$ of the men reported breakage and $9.5 \%$ reported PDE5i use during the last time a condom was used for PVI. Among men who had used PDE5i during the last condom-protected occasion of PVI, 11.9\% reported breakage compared with $5.3 \%$ of those not reporting PDE5i use. Adjusting for men's age, ethnic minority status, marital status, reported duration of PVI and alcohol use at last PVI, those using PDE5i were about four times more likely to also report condom breakage (AOR 4.02; $95 \% \mathrm{Cl} 1.20$ to $13.48 ; p=0.04)$. Of note, duration of PVI was independently associated with breakage (AOR 1.36; Cl 1.02 to $1.83 ; p=0.04$ ).

Findings suggest that PDE5i use may potentially be associated with increased odds of condom breakage among some men.

Phosphodiesterase type 5 inhibitor (PDE5i) drugs have been widely used as a treatment for erectile dysfunction. ${ }^{1}$ Although generally regarded as effective and safe, these drugs have also been associated with increased rates of high-risk sexual behaviour and HIV transmission in some men. ${ }^{2}$ Whether PDE5i increase the odds of condom breakage has not been studied. Breakage is not uncommon and largely negates the protective value of condoms relative to the prevention of pregnancy or sexually transmitted infections. ${ }^{3-5}$ Given the enhanced erections provided by PDE5i, it is plausible that condoms become more tight-fitting. Tight-fitting condoms have been associated with breakage. ${ }^{6-9}$

\section{METHODS}

\section{Study sample}

A convenience sample $(n=440)$ was recruited via advertisements in newspapers (two urban and one small town) and a blog on the website of a condom sales company that directed men to the questionnaire that was posted on the website of The Kinsey Institute. Inclusion criteria were male, at least 18 years old, used condoms for penile-vaginal intercourse (PVI) in the past 3 months and the ability to read English.

\section{Measures}

Assessments focused on the last condom use event for PVI. Condom breakage, PDE5i use and three covariates-duration of PVI, degree of vaginal lubrication and alcohol use (previously shown to be related to condom breakage ${ }^{9}$ - — were assessed by asking the following questions, respectively:

Thinking about the last time you used a condom for PVI..

Q1. Did the condom break during PVI? (no, yes, I don't know)

Q2. Did you use Viagra, Cialis or Levitra? (no, yes)

Q3. How long was your penis in the vagina? (less than a minute, 1-5, 6-10, 11-15, 16-20, 21 or more minutes)

Q4. How well lubricated was your partner's vagina? (very well lubricated (moist and slippery), adequate lubrication (no dry feeling), not quite enough lubrication (a little dry), poorly lubricated (very dry))

Q5. Were you drinking alcoholic beverages? (no, 1-2, 3-5, more than 5 drinks; a drink equals 1 beer, glass of wine or shot of liquor)

\section{Data analysis}

Continuous covariates not meeting normality assumptions were dichotomised by a median split. Variables achieving a screening-level of bivariate significance $(p<0.15)$ with condom breakage or PDE5i use were entered into a multiple logistic regression model to calculate adjusted odds ratios (AOR), their 95\% confidence intervals (CIs) and respective $\mathrm{p}$ values.

\section{RESULTS}

\section{Characteristics of the sample}

Average age was 29.6 years (SD 10.1). Breakage was reported by 26 men (5.9\%) and 42 men (9.5\%) reported PDE 5i use. Table 1 shows descriptive information relative to the dichotomised measures.

\section{Bivariate associations}

PDE5i use, alcohol use and minority ethnicity achieved screening significance (table 1). Table 1 displays the number of men responding "yes vs no" for each variable as well as the percentage of that number who reported condom breakage. For example, 42 reported PDE5i use and $11.9 \%$ of these $(n=5)$ also reported breakage compared with $5.3 \%$ $(n=21)$ of the 398 men not using PDE5i. Men's age and reported duration of PVI were preserved as continuous-level variables; therefore, bivariate associations were based on independent group $t$ tests. Age did not vary between men reporting breakage (mean age $=28.1$ years) and not reporting 
Table 1 Bivariate associations between dichotomous measures and condom breakage

\begin{tabular}{|c|c|c|c|}
\hline & $\%$ break* & $\mathrm{PR} \dagger(95 \% \mathrm{Cl} \$)$ & p Value \\
\hline \multicolumn{4}{|l|}{ Minority ethnicity } \\
\hline No $(n=371)$ & 4.9 & 2.39 (1.08 to 5.28$)$ & 0.029 \\
\hline Yes (69) & 11.6 & & \\
\hline \multicolumn{4}{|l|}{ Single } \\
\hline No (135) & 6.2 & 1.20 (0.52 to 2.79 ) & 0.67 \\
\hline Yes (305) & 5.2 & & \\
\hline \multicolumn{4}{|c|}{$\begin{array}{l}\text { Used erection enhancing } \\
\text { drugs§ }\end{array}$} \\
\hline Yes (42) & 11.9 & 2.25 (0.90 to 5.67$)$ & 0.08 \\
\hline No (398) & 5.3 & & \\
\hline \multicolumn{4}{|c|}{$\begin{array}{l}\text { Partner's vagina well } \\
\text { lubricated§ }\end{array}$} \\
\hline No (190) & 6.3 & 1.12 (0.58 to 2.38 ) & 0.75 \\
\hline Yes (250) & 5.6 & & \\
\hline \multicolumn{4}{|l|}{ Used alcohol§ } \\
\hline No (249) & 7.9 & 1.78 (0.84 to 3.78 ) & 0.13 \\
\hline Yes (191) & 4.4 & & \\
\hline
\end{tabular}

*Defined as experiencing breakage the time a condom was used for penile-vaginal sex; †prevalence ratio; tconfidence interval; §pertaining to the last time a condom was used for penile-vaginal intercourse.

breakage (mean age $=29.7$ years) $(t=0.78$ (438); $p=0.43)$. However, duration of PVI score was significantly longer among those reporting breakage (mean score $=4.7$ ) versus those not reporting breakage (mean score $=4.0 ; \mathrm{t}=2.45$ (438); $\mathrm{p}=0.015$ ).

PDE5i users were significantly older (mean age 41.1 years) than non-users (28.4 years; $t=8.3(438) ; \mathrm{p}<0.0001)$. PDE5i use was significantly more common among married men (18.5\%) than single men $(5.6 \% ; \mathrm{p}<0.001)$.

\section{Multivariate associations}

The logistic regression model using age, minority status (no/ yes), single (no/yes), duration (scale 1 (less than 1 minute) to 6 (21 or more minutes)), alcohol use (no/yes) and PDE5i use (no/ yes) was significant $\left(\chi^{2}\right.$ with $\left.6 \mathrm{df}=16.01 ; p=0.01\right)$ and produced a satisfactory fit with the data (goodness of fit $\chi^{2}$ with $8 \mathrm{df}=9.45 ; \mathrm{p}=0.31$ ). Minority ethnicity (AOR 2.59; $95 \%$ CI 1.04 to $6.43 ; \mathrm{p}=0.04$ ), duration of PVI (AOR 1.36; 95\% CI 1.02 to $1.83 ; p=0.04$ ) and PDE5i use (AOR 4.04; 95\% CI 1.06 to $15.41 ; p=0.04)$ achieved multivariate significance.

\section{DISCUSSION}

In a controlled analysis, condom breakage was about four times more likely among men using PDE5i drugs. However, a previous study of an older sample found that some men still experience erection problems while trying to use condoms in spite of PDE $5 \mathrm{i}$ use. ${ }^{10}$ Such findings highlight the importance of further studies, including qualitative research, to examine implications for physicians prescribing PDE5i drugs.

Findings are limited by the validity of retrospective self-report and the use of a convenience sample. Although the use of eventspecific analysis adds considerable strength to the study, this feature precludes the use of a repeated measures design that would allow for within-person comparisons as a function of PDE5i use. Given support from further investigations regarding PDE5i use and condom breakage, counselling could emphasise the following messages: 1) use condoms large enough to fit the enhanced erections that may be experienced and 2) understand that longer duration of intercourse may be associated with increased risk of breakage. Because not all PDE5i use is through

\section{Key messages}

- Phosphodiesterase type 5 inhibitor (PDE5i) use may be a risk factor for condom breakage.

- Given further support for the hypothesis that PDE5i use is a risk factor for condom breakage, counselling messages to men being prescribed these drugs may need to include objectives designed to avert breakage.

- Men attending sexually transmitted infections clinics and reporting PDE5i use may also benefit from counselling designed to reduce their risk of condom breakage.

prescription, ${ }^{2}$ these same implications may also be relevant in sexually transmitted infections clinics.

Funding: Support for this project was provided, in part, by the Rural Center for AIDS/ STD Prevention, a joint project of Indiana University, University of Colorado and the University of Kentucky, and by The Kinsey Institute, Indiana University.

Competing interests: None.

Ethics approval: Obtained from the Indiana University Institutional Review Board.

Contributors: Study implementation and oversight was conducted by SAS and WLY RC, CAG, WLY and SAS each shared in the development of the questionnaire and the conceptualisation and writing of this manuscript. RC performed the analyses.

Sex Transm Infect 2009;85:404-405. doi:10.1136/sti.2009.036012

\section{REFERENCES}

1. Rosen RC, McKenna K. PDE-5 inhibition and sexual response. Ann Rev Sex Res 2002; 13:36-88.

2. Rosen RC, Catania JA, Ehrhardt AA, et al. The Bolger Conference on PDE-5 inhibition and HIV risk: implications for health policy and prevention. J Sex Med 2006;3:960-75

3. Richters J, Donovan B, Gerofi J. How often do condoms break or slip off in use? Int J STD AIDS 1993:4:90-4.

4. Grady WR, Tanfer K. Condom breakage and slippage among men in the United Sates. Fam Plann Perspect 1994;26:107-12.

5. Crosby RA, DiClemente RJ, Holtgrave DR, et al. Design, measurement, and analytic considerations for testing hypotheses relative to condom effectiveness against non viral STIs. Sex Transm Infect 2002;78:228-31.

6. Crosby RA, Yarber WL, Sanders SA, et al. Men with broken condoms: who and why? Sex Transm Infect 2007;83:71-5.

7. Crosby RA, Graham CA, Yarber WL, et al. If the condom fits, wear it: a qualitative study of young African American men. Sex Transm Infect 2004;80:306-9.

8. Crosby RA, DiClemente RJ, Yarber WL, et al. An event-specific analysis of condom breakage among African American men at risk of HIV acquisition. Sex Transm Dis 2008;35:174-8.

9. Reece M, Dodge B, Herbenick D, et al. Experiences of condom fit and feel among African American men who have sex with men. Sex Transm Infect 2007;83:454-7.

10. Sanders SA, Milhausen RR, Crosby RA, et al. Do phosphodiesterase type 5 inhibitors protect against condom-associated erection loss and condom slippage? J Sex Med 2009:6:1451-6.

\section{Commentary}

The article by Crosby and colleagues ${ }^{1}$ in the current edition of the journal suggests that the use of phosphodiesterase 5 inhibitors (PDE5i) (sildenafil, tadalafil and vardenafil) by men is associated with a significantly increased rate of condom breakage compared with men who use condoms but not PDE5i. This seems biologically plausible in that whatever the degree of a man's natural penile rigidity, PDE5i use can enhance that intensity of tumescence. ${ }^{2}$

The use of PDE5i in HIV and other sexually transmitted infection (STI) acquisition and transmission is of importance, particularly in men who have sex with men (MSM). In clinical 


\section{Is phosphodiesterase type 5 inhibitor use associated with condom breakage?}

R Crosby, W L Yarber, S A Sanders, et al.

Sex Transm Infect 2009 85: 404-405

doi: 10.1136/sti.2009.036012

Updated information and services can be found at:

http://sti.bmj.com/content/85/5/404.full.html

\begin{tabular}{|c|c|}
\hline & These include: \\
\hline References & $\begin{array}{l}\text { This article cites } 10 \text { articles, } 4 \text { of which can be accessed free at: } \\
\text { http://sti.bmj.com/content/85/5/404.full.html\#ref-list-1 }\end{array}$ \\
\hline & $\begin{array}{l}\text { Article cited in: } \\
\text { http://sti.bmj.com/content/85/5/404.full.html\#related-urls }\end{array}$ \\
\hline $\begin{array}{l}\text { Email alerting } \\
\text { service }\end{array}$ & $\begin{array}{l}\text { Receive free email alerts when new articles cite this article. Sign up in } \\
\text { the box at the top right corner of the online article. }\end{array}$ \\
\hline $\begin{array}{r}\text { Topic } \\
\text { Collections }\end{array}$ & $\begin{array}{l}\text { Articles on similar topics can be found in the following collections } \\
\text { Reproductive medicine ( } 27677 \text { articles) } \\
\text { Condoms ( } 224 \text { articles) } \\
\text { Screening (epidemiology) (6479 articles) } \\
\text { Screening (public health) (6501 articles) }\end{array}$ \\
\hline
\end{tabular}

Notes

To request permissions go to:

http://group.bmj.com/group/rights-licensing/permissions

To order reprints go to:

http://journals.bmj.com/cgi/reprintform

To subscribe to BMJ go to:

http://group.bmj.com/subscribe/ 